\title{
Perubahan Osmolaritas Pasien Hiperglikemia dengan Terapi Rehidrasi
}

\author{
Erik Irham Lutfi ${ }^{1}$ \\ ${ }^{1}$ Fakultas Ilmu Kesehatan Universitas Kadiri, Kota Kediri, Indonesia \\ erik.irham@unik-kediri.ac.id
}

\begin{abstract}
Introduction: Uncontrolled DM hyperglycaemia will cause an increase in osmolarity which will disrupt the body's fluid and electrolyte balance. Rehydration therapy will replace the composition of body fluids caused by hyperosmolarity. Observation of management of hyperglycaemia only focuses on looking at blood sugar levels after rehydration therapy is given without looking at the body's osmolarity as an indicator of body fluid balance. This study aims to analyse changes in osmolarity in hyperglycaemic patients receiving rehydration therapy.
\end{abstract}

Methods: This study was a comparative study with a prospective cohort approach. The number of samples in this study were 56 respondents with data collection using the consecutive sampling technique. Study sample of hyperglycaemic DM patients receiving rehydration therapy at the emergency room at a hospital in Tulungagung. The research instrument used an observation sheet. Data analysis used paired t-test.

Results: Based on bivariate analysis there are changes due to rehydration therapy in the osmolarity variable with $p$ value 0.000 .

Conclusion: Changes in osmolarity occur due to a decrease in blood glucose levels after fluid rehydration is carried out. This further proves that rehydration therapy is very effective in reducing blood glucose levels (hyperosmolarity) in the blood. Continuous osmolarity and hemodynamic examination are very necessary for hyperglycaemic patients with rehydration therapy to determine the effects of rehydration therapy as well as to determine the side effects of rehydration therapy so prevention can be done so that it does not become a problem causing emergency emergency situations.

Keywords: Hyperglycaemia, Osmolarity, Rehydration therapy

\begin{abstract}
Abstrak
Pendahuluan: Hiperglikemia yang tidak terkontrol menyebabkan peningkatan osmolaritas yang akan menganggu keseimbangan cairan dan elektrolit tubuh. Terapi rehidrasi akan mengganti komposisi cairan tubuh yang ditimbulkan akibat hiperosmolaritas. Observasi tatalaksana hiperglikemia hanya berfokus melihat kadar gula darah sewaktu setelah terapi rehidrasi tanpa melihat osmolaritas tubuh sebagai indikator keseimbangan cairan tubuh. Penelitian ini bertujuan untuk menganalisis perubahan osmolaritas pada pasien hiperglikemia yang mendapatkan terapi rehidrasi.
\end{abstract}


Metode: Jenis Penelitian termasuk penelitian komparatif dengan pendekatan cohort prospektif. Jumlah sampel dalam penelitian ini sebanyak 56 responden dengan pengambilan data menggunakan teknik consequtive sampling. Sampel penelitian pasien DM hiperglikemia yang mendapatkan terapi rehidrasi di IGD RSUD dr. Iskak Tulungagung. Instrumen penelitian mengguanakan lembar observasi. Analisa data bivariat mengunakan paired t-test.

Hasil: berdasarkan uji analisis bivariat terdapat perubahan akibat terapi rehidrasi pada variabel osmolaritas dengan p value 0,000 .

Kesimpulan: Perubahan osmolaritas terjadi akibat adanya penurunan kadar glukosa darah setelah dilakukan rehidrasi cairan. Hal ini semakin membuktikan bahwa terapi rehidrasi sangat efektif dalam menurunkan kadar glukosa darah (hiperosmolaritas) di dalam darah. Pemeriksaan osmolaritas dan hemodinamika yang berkesinambungan sangat diperlukan bagi pasien hiperglikemia yang mendapatkan terapi rehidrasi untuk mengetahui efek terapi rehidrasi maupun untuk mengetahui efek samping dari terapi rehidrasi.

Kata kunci: Hiperglikemia, Osmolaritas, Terapi rehidrasi

\section{PENDAHULUAN}

Hiperglikemia menjadi permasalahan global tidak terkecuali di Indonesia (Soelistijo et al., 2015). Kekurangan insulin merupakan penyebab terjadinya hiperglikemia (Gotera, \& Budiyasa, 2010); American Diabetes Association [ADA], 2014). Kejadian hiperglikemia dapat memicu terjadinya penurunan sekresi insulin yang akibatnya meningkatkan resistensi insulin (Arifin, Natalia, \& Kariadi, 2010). Resistensi insulin akan membentuk suatu lingkaran yang samasama membuat kerugian dimana hiperglikemia meningkat akan menyebabkan produksi insulin dalam tubuh semakin berkurang (Arifin et al., 2010).

Hiperglikemia yang tidak terkontrol akan menyebabkan hiperosmolaritas (Barski, Kezerle, Zeller, Zektser, \& Jotkowitz, 2013). Hiperosmolaritas menstimulasi proses diuresis osmotik dalam tubuh, sehingga cairan dan elektrolit intra sel keluar ke ekstra sel. Perpindahan cairan ini menyebabkan sel mengalami penurunan komposisi cairan tubuh dan menyebabkan dehidrasi (Tokuda et al., 2010).

Tatalaksana utama hiperglikemia dengan pemberian terapi cairan atau rehidrasi (Bajwa, Baruah, Kalra, \& Kapoor, 2014; Nyenwe \& Kitabchi, 2016). Terapi cairan pasien hiperglikemia akut akan memberikan efek adanya penurunan kadar glukosa darah pada pasien hiperglikemia ( $80 \%$ pasien pada empat jam pertama (Gotera \& Budiyasa, 2010). Terapi cairan pada awalnya ditujukan untuk memperbaiki volume intravaskular dan extravaskular dan mempertahankan perfusi ginjal (Leksana, 2015). Terapi cairan juga akan menurunkan kadar glukosa darah tanpa bergantung pada insulin, dan menurunkan kadar hormon kontra insulin sehingga memperbaiki sensitivitas terhadap insulin (Zeitler, Haqq, Rosenbloom, \& Glaser, 2011).

Jenis cairan yang diberikan sesuai dengan pedoman tatalaksana kegawatan hiperglikemia adalah cairan isotonik $(\mathrm{NaCl}$ $0,9 \%$ ) dengan dosis pemberian sebanyak $10-20 \mathrm{ml} / \mathrm{kgBB} / \mathrm{jam}$ menyesuaikan dengan kondisi tubuh (fungsi jantung, pembuluh 
darah dan fungsi ginjal) (ADA, 2014). Pemberian larutan isotonis sangat efektif dalam pemenuhan kebutuhan cairan dari pada cairan lainnya terutama cairan isotonis normal saline 0,9\% (Chua et al., 2012). Hal terpenting dalam koreksi hiperglikemia dengan rehidrasi cairan adalah pemantauan pasien terus menerus terkait dengan status hemodinamikanya. Hal ini bertujuan untuk mencegah munculnya komplikasi akibat pemberian terapi, yaitu kelebihan volume cairan pada ekstra sel dan gangguan keseimbangan elektrolit akibat pemberian elektrolit tubuh dari luar (Bakes et al., 2016).

Terdapat beberapa penelitian, tentang efek rehidrasi terhadap komponen osmolaritas, yaitu kadar gula darah, seperti Chua et al. (2012) dan Bakes et al. (2016), dimana rehidrasi dapat menurunkan kadar gula darah pasien hiperglikemia, akan tetapi belum mengambarkan kondisi osmolaritas tubuh secara keseluruhan yang ditimbulkan akibat hiperglikemia, karena osmolaritas diketahui dengan menghitung nilai dari serum elektrolit natrium, ureum dan kadar glukosa darah (Nyenwe \& Kitabchi, 2016). Oleh karena itu, penelitian ini Ingin menganalisis perubahan keseluruhan komponen osmolaritas pada pasien hiperglikemia dengan terapi rehidrasi.

\section{METODE}

Penelitian ini termasuk penelitian analitik komparatif dengan pendekatan cohort prospektif. Pendekatan ini digunakan karena peneliti mengambil data setelah program terapi rehidrasi diberikan sampai program terapi dihentikan atau dimodifikasi dengan metode lain seperti terapi rehidrasi kombinasi insulin. Pengukuran hemodinamika di lakukan sebanyak 3 kali pengukuran dengan pembagian waktu (sebelum, di dalam program terapi dan sesudah pemberian terapi rehidrasi diberikan). Pengambilan data dilaksanakan selama 6 minggu dimulai pada tanggal 05 Juni-16 Juli 2017, bertempat di Instalasi Gawat Darurat (IGD) di sebuah rumah sakit di Tulungagung. Jumlah responden dalam penelitian ini sebanyak 56 responden. Karakteristik responden pada penelitian ini adalah pasien hiperglikemia akut maupun hiperglikemia krisis yang dilakukan perawatan di IGD baik di ruang red zone maupun yellow zone yang mendapatkan terapi rehidrasi. Pengumpulan data responden dengan menggunakan teknik consecutive sampling sesuai dengan kriteria inklusi yaitu: pasien hiperglikemia dengan kadar gula darah sewaktu lebih dari $200 \mathrm{mg} / \mathrm{dl}$, menjalani terapi rehidrasi cairan isotonis $\mathrm{NaCl}$ 0,9\% sebanyak 10-20 $\mathrm{ml} / \mathrm{kgBB} / \mathrm{Jam}$, dan bersedia menjadi responden. Analisis data dalam penelitian ini menggunakan paired t-test.

\section{HASIL}

Dari tabel 1 hampir setengah responden penelitian berusia diantara 4145 tahun sebesar 33,9\%, usia terendah responden berada pada kisaran 31-40 tahun sebanyak $3,6 \%$ responden dan terdapat $7,1 \%$ responden yang berada pada rentang usia 71-90 tahun ketika mengalami hiperglikemia.

Tabel 1. Distribusi Usia Responden

\begin{tabular}{ccc}
\hline Kategori Usia & Jumlah & \% \\
\hline $31-40$ tahun & 2 & 3,6 \\
\hline $41-50$ tahun & 19 & 33,9 \\
\hline $51-60$ tahun & 16 & 28,6 \\
\hline $61-70$ tahun & 15 & 26,8 \\
\hline $71-90$ tahun & 4 & 7,1 \\
\hline Total & 56 & $100 \%$ \\
\hline
\end{tabular}


Tabel 2 menunjukkan bahwa 69,6\% responden menderita DM selama 1-5 tahun dan $1,8 \%$ memiliki riwayat menderita DM selama 16-20 tahun.

Tabel 2. Distribusi Lama Menderita DM

\begin{tabular}{lcc}
\hline $\begin{array}{c}\text { Kategori } \\
\text { Lama DM }\end{array}$ & $\mathbf{n}$ & $\mathbf{\%}$ \\
\hline $1-5$ tahun & 39 & 69,6 \\
\hline $6-10$ tahun & 12 & 21,4 \\
\hline $11-15$ tahun & 4 & 7,1 \\
\hline $16-20$ tahun & 1 & 1,8 \\
\hline Total & 56 & $100 \%$ \\
\hline
\end{tabular}

Tabel 3 menunjukkan bahwa hampir seluruh responden mendapatkan terapi rehidrasi sejumlah $1.000 \mathrm{ml}$ selama program terapi rehidrasi.

Tabel 3. Distribusi jumlah terapi rehidrasi

\begin{tabular}{ccc}
\hline $\begin{array}{c}\text { Jumlah } \\
\text { Terapi Rehidrasi }\end{array}$ & n & \% \\
\hline $500 \mathrm{ml}$ & 7 & 12,5 \\
\hline $1000 \mathrm{ml}$ & 46 & 82,1 \\
\hline $2500 \mathrm{ml}$ & 2 & 3,6 \\
\hline $3000 \mathrm{ml}$ & 1 & 1,8 \\
\hline Total & 56 & $100 \%$ \\
\hline
\end{tabular}

Grafik 1 menunjukkan bahwa terdapat perubahan rerata osmolaritas sebelum dan sesudah diberikan terapi rehidrasi rerata sebelum terapi adalah 303,8 dengan SD 21,21 sedangkan setelah dilakukan terapi rehidrasi didapatkan adanya penurunan sebesar 5,91 menjadi 297,89 dengan SD 20,982 .
Grafik 1. Perubahan Osmolaritas Sebelum dan Sesudah Terapi Rehidrasi

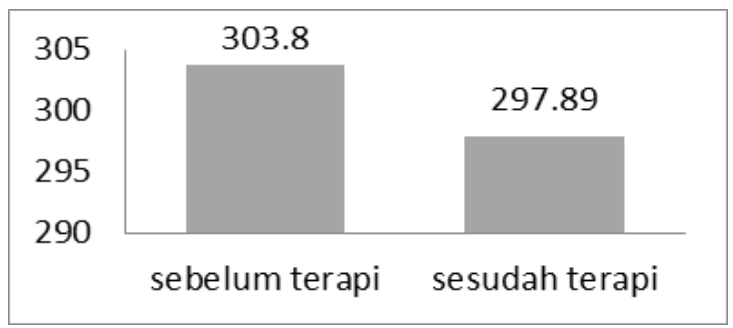

Berdasarkan grafik di atas, diketahui rerata sebelum terapi adalah 303,8 dengan SD 21,21 sedangkan setelah dilakukan terapi rehidrasi didapatkan adanya penurunan sebesar 5,91 menjadi 297,89 dengan SD 20,982. Hasil analisis memperlihatkan ada perubahan osmolaritas tubuh sebelum dan sesudah dilakukan terapi rehidrasi dengan perbedaan sebesar 5,91 mengarah ke nilai normal dengan $\mathrm{p}$ value $=0,000(\alpha<$ $0,005)$.

Tabel 4. Perubahan Osmolaritas Tubuh Sebelum dan Setelah Terapi Rehidrasi

\begin{tabular}{rcccc}
\hline Perlakuan & n & Mean & SD & $\boldsymbol{p}$ \\
\hline Sebelum & 56 & 303,8 & 21,211 & 0,000 \\
\hline Sesudah & 56 & 297,8 & 20,982 & \\
\hline
\end{tabular}

\section{PEMBAHASAN}

Penilaian osmolaritas pada penelitian ini mempertimbangkan tiga indikator utama osmolaritas, yaitu nilai natrium, ureum, dan kadar gula darah sewaktu. Nilai osmolaritas didapatkan dengan cara nilai Natrium yang dikalikan dua ditambah nilai Ureum yang dibagi 2,8 dan ditambah nilai kadar gula darah sewaktu yang dibagi 18 .

Hasil penelitian menunjukkan bahwa terdapat perbedaan osmolaritas sebelum dan sesudah dilakukan terapi 
rehidrasi dengan perbedaan sebesar 5,91. Perbedaan ini mengarah ke nilai osmolaritas mendekati normal dimana yang sebelumnya tinggi di atas 300 menjadi di bawah 300, sehingga osmolaritas tubuh setelah diberikan terapi rehidrasi berubah menjadi lebih baik dengan $\mathrm{p}=0,000$ dengan $\alpha \leq 0,05$.

Adanya penurunan signifikan kadar gula darah setelah diberikan terapi, akan diikuti penurunan nilai osmolaritas tubuh. Adanya perbaikan osmolaritas pada kelompok responden penelitian ke arah mendekati normal (200-290 mos/kg) mean sebelum terapi rehidrasi $(303,80)$ berubah menjadi $(297,89)$ dapat meningkatkan keseimbangan cairan tubuh baik yang ada didalam intrasel maupun didalam ekstrasel. Hal ini akan memberikan manfaat akan terjadinya keseimbangan cairan tubuh sehingga komposisi tubuh akan seimbang dan risiko gangguan keseimbangan cairan tubuh tidak akan terjadi pada pasien DM hiperglikemia (Inzucchi et al., 2015).

Perbaikan osmolaritas ditandai dengan penurunan bermakna kadar glukosa darah sesuai dengan kriteria hasil yang diharapkan dari diagnosa keperawatan potensial komplikasi hiperglikemia yaitu mengusahakan adanya kadar glukosa darah dalam plasma dan urin dalam batas normal. Terapi rehidrasi cairan pada pasien DM hiperglikemia bertujuan untuk menjaga volume sirkulasi sentral dan perifer adekuat (Semawarima, 2017). Berdasarkan hasil penelitian, terapi rehidrasi cairan tubuh yang diberikan kepada responden di IGD RSUD seusai dengan kaidah dari ADA tahun 2014, dosis pertama adalah $10-20 \mathrm{ml} / \mathrm{kgBB} / \mathrm{jam}$, dengan cairan yang diberikan adalah jenis cairan isotonis yaitu $\mathrm{NaCl} 0,9 \%$ sebagai cairan rehidrasi.
Faktor utama perubahan osmolaritas pada penelitian ini adalah disebabkan oleh perubahan kadar glukosa darah, tidak ditemukan perubahan signifikan dari natrium dan blood urea nitrogen (BUN) dalam perubahan nilai osmolaritas setelah dilakukan pemberian terapi rehidrasi. Adanya penurunan kadar gula darah setelah dilakukan terapi rehidrasi sesuai dengan penelitian sebelumnya dimana terjadi penurunan kadar gula darah pada empat jam pertama pada $80 \%$ responden DM hiperglikemia (Gotera \& Budiyasa, 2010).

\section{KESIMPULAN DAN SARAN}

Berdasarkan hasil penelitian Analisis perubahan osmolaritas pada pasien hiperglikemia dengan terapi rehidrasi dapat disimpulkan terdapat perubahan osmolaritas tubuh pada pasien hiperglikemia sebelum dan sesudah terapi rehidrasi. Pemeriksaan osmolaritas dan hemodinamika yang berkesinambungan sangat diperlukan bagi pasien hiperglikemia yang mendapatkan terapi rehidrasi untuk mengetahui efek terapi rehidrasi maupun untuk mengetahui efek samping dari terapi rehidrasi.

\section{DAFTAR PUSTAKA}

American Diabetes Association. (2014). Diagnosis and classification of diabetes mellitus. Diabetes Care, 37(1), 581-590.

Arifin, A. L, Natalia, N., \& Kariadi, S. H. (2010). Krisis hiperglikemia pada diabetes melitus diperoleh dari http://pustaka.unpad.ac.id/wpcontent/uploads/2009/10/krisis_hip erglikemia_pada_diabetes_melitus. pdf. 
Bakes, K., Haukoos, J. S., Deakyne, S. J., Hopkins, E., Easter, J., McFann, K.,...Rewers, A. (2016). Effect of volume of fluid resuscitation on metabolic normalization in children presenting in diabetic ketoacidosis: A randomized Controlled trial. The Journal of Emergency Medicine, 50(4), 551-559. doi: 10.1016/j.jemermed.2015.12.003

Barski, L., Kezerle, L., Zeller, L., Zektser, M., \& Jotkowitz, A. (2013). New approaches to the use of insulin in patients with diabetic ketoacidosis. European Journal of Internal Medicine 24(3): 213-216. doi: 10.1016/j.ejim.2013.01.01

Bajwa, S. S., Baruah, M. P., Kalra, S., \& Kapoor, M. C. (2014). Guidelines on inpatient management of hyperglycemia diperoleh dari http://www.apiindia.org/medicine_ update_2013/chap35.pdf

Leksana, E. (2015). Strategi terapi cairan pada dehidrasi. $C D K-224,42(1)$, $70-73$.

Gotera, \& Budiyasa. (2010). Penatalaksanaan Ketoasidosis Diabetik (KAD). Journal of Internal Medicine, 11(2), 126-138.

Medicina, 48(1), 49-53. doi: 10.15562/medi.v48i1.25

Soelistijo, S. A., Novida, H., Rudijanto, A., Soewondo, P., Suastika, K., Manaf, A.,...Zufry, H. (2015). Konsensus pengelolaan dan pencegahan diabetes tipe 2 di Indonesia 2015. PB. PERKENI. Diperoleh dari https://pbperkeni.or.id/wpcontent/uploads/2019/01/4.-
Konsensus-Pengelolaan-dan-

Pencegahan-Diabetes-melitus-tipe-

2-di-Indonesia-PERKENI-2015.pdf

Tokuda, Y, Omata, F, Tsugawa, Y, Maesato, K, Momotura, K, Fujinuma A.,...Cook, E.F. (2010). Vital sign triage to rule out diabetic ketoacidosis and nonketotic hyperosmolar syndrome in hyperglycemic patients. Diabetes Research and Clinical Practice 87(3); 366-371. doi: 10.1016/j.diabres.2009.11.020

Zeitler, P., Haqq, A., Rosenbloom, A., and Glaser, N. (2011). Hyperglycemic hyperosmolar syndrome in children: Pathophysiological considerations and suggested guidelines for treatment. The Journal of Pediatrics, 158(1), 1914.e2. doi:

10.1016/j.jpeds.2010.09.048 